\title{
CHALLENGING THE OPPRESSIVE SOCIAL CONTEXT BY REDESIGNING LEARNING SPACE. THE CASE OF A BUSINESS ETHICS CLASS IN RUSSIA*
}

\author{
Polina Kalnitskaya**
}

doi: 10.11144/Javeriana.cao31-57.cosc. Reflection paper. Received: 26/07/2017. Accepted: 14/11/2018. Cited as: Kalnitskaya, P. (2018). Challenging the oppressive social context by redesigning learning space. The case of a business ethics class in Russia. Cuadernos de Administración, 31(57), 79-103. http://dx.doi. org/10.11144/Javeriana.cao31-57.cosc.

** Master in Journalism of Rostov State University, Rostov-on-Don, Russia,1994. Profesor of Higher School of Economics, Moscow, Russia.

E-mail:pkalnitskaya@gmail.com 
Challenging Aвstract. The traditional management educational methods like in class the oppressive social context by redesigning learning space. The case of a business ethics class in Russia group activities derive from Western democratic principles and work well in tolerant and pluralistic climate. However, in dogmatic and oppressive social environment, they just reinforce the dominant culture and create obstacles to fostering the students' critical reflexive thinking. Learning space becomes constrained by different overwhelming contextual factors: from group pressure to an authoritarian political background. On the case of the Russian business ethics classroom, this paper examines the influence of an oppressive context on the learning space and offers an approach to weakening this influence by intensifying students' critical reflexivity using writing assignments and supportive teacher's feedback based on a narrative therapy approach.

Keywords: ethics, management education, Russia, reflexivity. JEL Codes: M14, M19

Desafiar el contexto social opresivo rediseñando el espacio de aprendizaje. El caso de una clase de ética empresarial en Rusia

Desafiar o contexto social opressivo redesenhando o espaço de aprendizagem. 0 caso de uma classe de ética empresarial em Rússia
Resumen. Los métodos educativos tradicionales en administración, como las actividades de grupo en clase, se derivan de los principios democráticos occidentales y funcionan bien en un clima tolerante y pluralista. Sin embargo, en un entorno social dogmático y opresivo, simplemente refuerzan la cultura dominante y crean obstáculos para fomentar el pensamiento reflexivo crítico de los estudiantes. El espacio de aprendizaje se ve limitado por diferentes factores contextuales que abruman a los estudiantes: desde la presión del grupo hasta el historial político autoritario. En el caso del aula rusa de ética empresarial, este artículo examina el papel de un contexto opresivo en el espacio de aprendizaje y ofrece un enfoque para debilitar esta influencia mediante la intensificación de la reflexividad crítica de los estudiantes. Esto se consigue a través de tareas de escritura y de la retroalimentación de apoyo del profesor, basada en un enfoque de terapia narrativa.

Palabras clave: ética, educación empresarial, Rusia, reflexividad. Códigos JEL: M14, M19

Resumo. Os métodos educativos tradicionais em administração, tais como as atividades de grupo em classe, derivam-se dos princípios democráticos ocidentais e funcionam em um clima tolerante e pluralista. Contudo, em um entorno social dogmático e opressivo, simplesmente reforçam a cultura dominante e criam obstáculos para fomentar o pensamento reflexivo crítico dos estudantes. O espaço de aprendizagem vê-se limitado por diferentes fatores contextuais que constrangem aos estudantes: desde a pressão do grupo até o historial político autoritário. No caso da aula russa de ética empresarial, este documento examina o papel de um contexto opressivo no espaço de aprendizagem e oferece um enfoque que debilita esta influência por meio do incremento da reflexividade crítica dos estudantes. Isto se consegue a través de tarefas de escrita e da retroalimentação de apoio do professor, baseada em um enfoque de terapia narrativa.

Palavras chave: ética, educação empresarial, Rússia, reflexividade. Códigos JEL: M14, M19 


\section{Introduction}

Over the past few decades, the Western model of management education has become widespread around the world. Since it is one of the most practical types of education for business managers, it is aimed at obtaining practical (as opposed to theoretical) knowledge and developing skills that can be applied in business in any cultural context. Today, there are various recommendatory materials that provide methodological support in this area of teaching, for example, SAGE Business \& Management library, the Case Center or the PRME Anti-Corruption Toolkit to name just a few. These materials, according to some of the descriptions made by their authors, are "designed to engage students in applying core concepts to practice through the use of examples from the global business environment" (https://sk.sagepub.com/about-business-cases\#About). They are "dedicated to advancing the case method worldwide, sharing knowledge, wisdom and experience to inspire and transform business education across the globe" (https://www.thecasecentre.org/main/aboutus/organisation/whatwedo) and "provide comprehensive guidelines for anti-corruption curriculum change in business schools and higher education institutions around the world" (http://www.unprme.org/resource-docs/ PRMEACWGEnglish.pdf).

These teaching methods are considered effective are versatile. In particular, various types of group activities in the classroom - topic discussions and case studies - have already become traditional methods of training for managers, which are applied in different countries. Many Russian business schools have taken some steps toward adjusting their programs to meet Western standards (Mechitov \& Moskovich, 2004). For the paradigm based on the thinking that "management education is just a set of tools and skills," that works. But this paradigm is ignoring an environment - the social context, in which these tools and skills are obtained.

The attitude towards business tools and methods of teaching derives from Western democratic principles: each person is viewed as an independent personality, making their own choices freely, expressing their opinions openly, and having sufficient personal resources to win in a free competition. Under such conditions, group learning methods work quite well, free exchange of opinions enriches the picture of the world of all the participants of the discussion. However, what if these methods are used in nondemocratic, i.e. authoritarian, oppressive social contexts? What purposes will these tools and methods serve? Researchers argue that in oppressive societies, traditional methods of 
education do not only prove ineffective, but also become part of the oppressive system (Shoukry, 2016). Practical focus on improvement within the boundaries of a social system reinforces the dominant culture and distracts from a critical look towards the whole system (Marcuse, 1991; Habermas, 1970).

This paper developed from two questions that I had been asking myself while teaching business ethics in Russia: How does oppressive social context influence the classroom in management education? and What can be done to weaken this constraining influence?

I would like to study an the example of teaching business ethics in Russia in order to examine the influence of contextual factors on the learning space and, based on the results of this study, to offer an approach that would allow the teacher to weaken this influence in order to turn learning space into a more effective ground for development, empowerment, and freedom, thus making the studying process more advantageous for students' personal and professional growth.

First, I will explore the influence of various contextual factors on the learning space on the example of the Russian business ethics class. Further, I will share the experience of restructuring the learning space by intensifying of out-of-class activity aimed to develop critical reflexivity as a fundamental skill for managers, who take into consideration the ethical dimension in the process of making managerial decisions.

The philosophical concept at the core of my research is the result of integration of three sources: social constructionism (Berger \& Luckmann, 1966), the concept of rigid framing -including the ideas of Palazzo, Krings and Hoffrage (2013) on the influence of distal and proximal factors of social context on how people perceive and interpret the world-, and a narrative approach in psychology. I also use the ideas of researchers Louis and Fatien Diochon (2018) on the impact of the social context on learning space. As a means of relieving the influence of the oppressive environment, I use written practices based on the ideas on the development of critical reflexivity expressed by Cunliffe, Jørgensen, and Fatien Diochon (2018). Another practical tool is the exercise from Giving Voice to Values - curriculum an innovative approach to values-driven leadership in business education and the workplace (https://www.darden.virginia.edu/ibis/initiatives/giving-voice-to-values/). 


\section{The influence of social context on learning space}

For the purposes of this paper and along the lines of Kolb's idea that learning is a transaction between a person and the social environment (Kolb \& Kolb, 2005), I define learning space not simply as physical space, in which classes take place, but as extended space, including both in-person and virtual classes. My vision of learning space also includes learning materials provided to students, as well as the special social environment created by the interaction between the teacher and the students or the communication among the students, both in class and in virtual reality.

Developing ethical thinking and reasoning in management education is far more than intrapersonal philosophizing: it is a much more rhetorical and performative exercise done in interaction with others. Expressing judgments, defending one's own point of view, sharing personal experience and stories are the main elements of the ethics classroom activity for managers.

Learning spaces are delicate, fragile, and limited by different contexts influencing them through the actions of the people, who create this space. Learning spaces can be both empowering and limiting depending on situational and social contexts that influence them (Louis \& Fatien Diochon, 2018).

From the perspective of the constructionist view on social life, individuals have no direct access to reality: they perceive the world through the mental structures - cognitive frames - that simplify complex reality and facilitate understanding of information, situations, and expectations (Gioia, 1992). These frames filter what people see and how they see it, making the people view the world from one particular and limited point. Using cognitive frames often results in rigid framing that seriously limits the ability to see the more varied picture of the world. However, individuals are not aware of this fact; they believe that the picture is complete and ignore information that does not fit into their framework. Rigid framing is related to (dangerously) narrow and limited sensemaking.

People develop and use cognitive frames in the process of interacting with different contexts and environments. Sensemaking depends on the context factors "that can amplify or attenuate a specific way in which a frame is used" (Palazzo, Krings \& Hoffrage, 2013).

In their study of ethical blindness -temporary inability of a decision maker to see the ethical dimension of a decision at stake- Palazzo, Krings \& Hoffrage (2013) argue 
that flexible framing is better than rigid framing, because it reduces the risk of ethical blindness and, ultimately, of unethical behavior. Ethical decisions depend on moral imagination and the person's ability to recognize and take into account various aspects of a problema (Arendt, 1963).

Flexible framing and moral imagination blossom in tolerant and pluralistic climate. "The most effective cure for ethical blindness is an atmosphere of open, democratic, and critical deliberation" (Palazzo, Krings, \& Hoffrage, 2013).

But in dogmatic and oppressive social context people are indoctrinated ideologies, which legitimate the interest of the dominant group. They accept as natural and even desirable an unjust social order and become ready to defend it, that spreads to the unconscious assumptions and attitudes of well-meaning people in everyday life (Young, 2000). Individuals can lose the ability to challenge the status quo (Brookfield, 2005).

Individuals engage in performing and storytelling in learning space through their (often rigid) frames. The voice is given to some ideas, stories, and beliefs, while others are labelled as unacceptable or even completely pushed out of sight and discussion. During the class activity, dominant mindsets are determined and voiced while others are censored and silent. Depending on how social context influences the learning space, it can be encouraging and empowering, making frames more flexible - or limiting and oppressive, promoting rigid framing.

Talking about the decision making process in organizations, Palazzo, Krings, and Hoffrage (2013) distinguished between distal and proximal context. I believe that it makes sense to apply the same approach to learning space. Distal context includes the broader social, cultural and political frameworks, in which a teacher, students, and educational institutions are embedded. The immediate situation and the given educational institution setting comprise proximal context that affects learning space.

\section{The distal context of the Russian classroom}

\section{Political and economic context}

Researchers and experts describe the Russian post-soviet political and economic development as the time of initial liberalization and subsequent re-etatization in the 2000s. The Russia's route is conceptualized as neoliberalism, statism and patrimonialism 
(Becker \& Vasileva, 2016, Matveev, 2016). Instead of a rational western capitalism, a patrimonial one has been formed, on the basis of insider control of enterprises' financial streams rather than on private property rights. Russian neoliberalism is not just a regime of budgetary austerity, but a specific selection of governance techniques based on market logic, but implemented inconsistently and in contradictory, hybrid forms. Re-etatization undermined liberalization, and the state property expansion resulted in the fact that "Russia's economy wasn't so much taken over the state, as the state was transformed into its own kind of corporation - with the appropriate arrangements and managerial models" (Matveev, 2016). Rosneft and Gazprom, public companies, but controlled by the state, dominate the oil and gas sector. State corporations with highly beneficial conditions took control of the military industrial complex and innovations. But various functions of the state, mostly in the social sector, are privatized. Authorities are cutting the funding and limiting access to free health care and high-quality education.

All these didn't become drivers of economic prosperity for ordinary Russian citizens. Russia is one of the most unequal world's major economies: the top decile of wealth holders owns $77 \%$ of all household wealth, according to a recent report by Credit Suisse (2017). Russia ranked 135th out of 180 countries in Transparency International's Corruption Perceptions Index 2017 (Transparency International, 2017). The minimum wage is about $\$ 178$.

This method of conducting reforms has fuelled an authoritarian drift. The political system constructed by the ruling elite is personalist autocracy with a dominant role played by Vladimir Putin. Against the Russian law, political rights and freedoms are limited in practice. Freedom of speech and meetings is not respected (Freedom House, 2018). 0pposition politicians, activists and people who criticize the activities of the federal and regional authorities are persecuted (Memorial, 2017). With the help of intensive state propaganda, the conservative ideology of traditionalism, national-patriotic pride and military might is established, whereas establishment of any single ideology is prohibited by the Constitution of Russian Federation. State-controlled Russian media create the picture of confrontation with the Western countries: "them against us" (Levada-Center, 2016, Paul \& Matthews, 2016, Ukraine Crisis Media Center, 2018).

Some political scientists view modern Russian state system as a hybrid regime: and imitation democracy, or electoral authoritarianism (Schulmann, 2014); according to the same author, the hybrid regime is a new historical stage of authoritarianism. It is characterized by the decorative, imitative character of democratic institutions. In hy- 
brid regimes, elections are held, but the authorities do not change. There are several TV channels, but they all say the same thing. There is an opposition, but it is not opposed to anyone. The hybrid regime is an imitation on two levels: it does not only simulate democracy, which in fact does not exist in the country, but also imitate a dictatorship. Notably to this type of social arrangement, state propaganda does not mobilize anyone. It unites citizens on the principle of passivity.

\section{Russian (non) traditional values}

Russian political elite officially offers conservative values to the society. A discourse of "European values against Russian traditional values" has appeared. Despite the fact that state propaganda and pro-governmental public opinion research centers give the impression that Russians are very religious and support conservative discourse, while independent research projects suggest the opposite.

The World Values Survey (http://www.worldvaluessurvey.org) has found out that Russians pay a low respect for traditions.

The World Values Survey is a global research project that explores people's values, how they change over time, and what impact they have on political and social contexts. The survey is based on assumptions that there are two major dimensions of cultural variations in the world:

- Traditional values versus Secular-rational values; and

- Survival values versus Self-expression values.

Traditional values emphasize the importance of religion, traditional family values, deference to authority. People who embrace these values reject euthanasia, suicide, divorce, and abortion. Societies that embrace such values usually have a nationalistic mindset. Secular-rational values consider authority, traditional family, and religion as less important. Abortion, divorce, suicide, and euthanasia are relatively acceptable.

Self-expression values are about equality, tolerance, environmental protection and rising demands for participation in political and economical decision making. Survival values accentuate economic and physical security. Societies have a low level of equality, trust, and tolerance. 
According to the WVS findings, Russia is a secular society, on the same level with Hungary, Spain, Belgium, Austria and France (Paneyakh, 2016). Russians support universal basic values of the European civilization. Materialistic values are of great significance, the values of consumerism have been firmly assimilated. For most of the young people, the typical values of the consumer society are significant: work, family, success, entertainment. Young people show a higher value differentiation than the older generation. Age differences play a more significant role than the level of income (Golovin \& Sibirev, 2016).

In terms of self-expression values, Russians lag far behind many developed countries and are on par with Serbia, Bosnia, Romania, Iraq, and Jordan. The survival values prevail. Russians value stability highly (Paneyakh, 2016).

So, the values of Russians are quite universal, but weak. Experts note an unfortunate combination of two factors: 1 ) people do not strongly believe in generally accepted values, 2) the established system has created structural limitations for value-oriented behavior. There is a strict framework of bureaucracy and authoritarianism at all levels. The problem is not the people, but the restrictive social structures. Value selection is carried out within a narrow framework. People are not ready to make sacrifices for the sake of values, but they are also put in such conditions, when they have to sacrifice all at once (Paneyakh, 2016).

In fact, the ruling elite imposes on the Russian society the values that are not organic to it. Despite the weak faith of Russians in values, according to scientists, there is no threat of cultural recession in the Russian society (Golovin \& Sibirev, 2016).

The level of trust is an important indicator of the condition of the society. The general atmosphere of trust is a characteristic of the effectiveness and significance of the social institutions, and a low level of trust means bad social integration, the existence of numerous uncoordinated social orders, and deficit of social capital. Interpersonal trust in Russia is not just low, it has also been steadily declining for the past 10 years. The incidence of a sense of interpersonal trust depends little on age and education. The connection with a level of income is nonlinear. The maximum trust is shown by people with an average level of income. The problem of trust is seen by researchers as the most important than issues of freedom, justice, law, order and civic engagement. Reducing the prevalence of these characteristics of social relations in Russia is less than the narrowing of the zone of interpersonal trust (Levada center, 2013). A low level of trust entails ineffective economic co-operation and can slow down economic growth. 
A sense of injustice prevails among Russians: only 34 percent expect an honest and fair attitude to themselves. Even less numerous those who believe that everything can be achieved without violating the rules adopted in the society - 29 percent (Levada center, 2013).

Trust is closely related to the notion of social and personal responsibility and the opportunities to realize this responsibility, which means the capacity to control and influence the events of both one's own life and the life of the society. It may seem-that the level of control among Russians is high, but the area of this control is limited to a close circle of communication. According to Levada center study (2013), 90\% of Russians believe that they can influence life in their family. $51 \%$ of respondents can control the workplace. The level of the city or country is outside the boundaries of views of Russians - 9 out of 10 respondents do not see any opportunity to influence these levels. Delegating responsibility to the state along with civic passivity are obstacles to social development. This is a legacy of the Soviet era, when any grassroots initiative was suppressed. The suppression of civic engagement is what is happening in modern Russia.

In contrast to the indicators of trust, the possibilities of control are more dependent on age and education. Young and more educated are more likely to be confident in their own abilities. The dynamics of confidence in the ability to control the circumstances of one's own life increases with the growth of income (Levada center, 2013).

Along with the fall in the level of trust, there is another important aspect of public relations, because it affects many things, including the styles of management and communications. It is the gender issue. The implantation of traditional values occurs, among other things, in shaping the image of Putin as a strong leader and a strong man. Since this trend was set by the ruling elite, the other participants of the political process are having to adjusted.

In the contemporary Russian case, the Kremlin deployed a legitimation strategy that included stressing Putin's machismo - a strategy that bled into popular cultural productions of the same ilk. This evoked a similarly gendered response from those opposed to the Putin-centered regime. The resulting political interactions have included homophobic discourse along with competing for claims to femininity and masculinity both by regime supporters and detractors. (Sperling, 2014, p. 3) 
An assertion of masculinity become a vehicle for power. The level of misogyny grows and reduces women and femininity to a lower level of status and power in society. Despite the fact that sexism, racism, ageism, and ableism are prohibited by Russian law, they are common phenomena in the workplace in Russia. The society does not understand and does not recognize these phenomena, because public gender discourse is captured by pro-government speakers broadcasting patriarchal values and gender stereotypes. Any public discussion of these issues, including discussion in social media, immediately turns into hype, often with elements of verbal and non-verbal violence by patriarchal advocates, who see themselves as the bearers of the right ideology in isolation from the "disintegrating European values".

\section{Russian management style}

The situation described above does not leave a mystery of what features characterize the Russian style of management. Both insiders and researchers are unanimous in the opinion that the main feature of Russian management is authoritarianism. In the Russian culture, the autocratic management style is considered to be the most efficient one. Leaders are straightforward and strict, guided by a rigid hierarchy. Punishment is an integral part and core element of corporate culture; at the same time, a leader is expected to be paternalistic and protective of his subordinates (Yushina, 2014). International expert on management Ichak Adizes says,

A manager, leader, seeks and will fight whoever challenges their authority. There is an air of superiority that any leader in Russian organization has to demonstrate. Cannot admit to being fallible. A leader, by admitting to not knowing it all, fears he or she might lose authority, because it is expected from them to know it all. (Adizes, 2013)

Everyone talks about democracy and wants it, but open-minded and free-thinking managers are squeezed out of Russian companies. Autocracy leads to the need for control. Russian leaders are eager to talk about fashionable practices: agile, gamification, work without an office. But all this is hampered by the high level of control and fear in companies. People are afraid to speak up. Other characteristics of the Russian management style are productivity without efficiency, bureaucracy, corruption, little attention to people's interests, using a large amount of data in decision-making, and using political influence and resources in public administration (Yushina, 2014, Adizes, 2013). 
The thinking of a typical Russian manager is technocratic. Functionalist performance centrism is expected. Instrumental and positivist approaches are prevalent. Utilitarianism is the dominant moral reasoning in Russian business environment. It is widely believed that Russian culture in general, and business in particular, is built on some other motivation, different from material, some kind of spiritual motivation, unlike the Western world. At the same time, business is regarded as something exceptional in human activity, where, like in a war, the usual norms of morality do not seem to work.

The cultural and social background described above moulds the prevalent communication style in Russia, both in public and at a workplace. This style is mainly characterized by machismo, the cult of power and aggression. There is a lot of propaganda, speeches, and pseudo-collective actions that go along these lines. The spontaneous communication that is not prepared and approved by the authorities -for example, in the form of grassroots collective actions and public speeches- is brutally suppressed.

People lack practice of debate and skills for maintaining respect for the interlocutor and suppressing the desire to win at all costs while discussing hot social issues. Both the authoritarian style of governance and the notion that business is at best a sport, and at worst a war (the metaphor of war is very evident in business discourse) play an important role in the formation of business communication (and communication in business education). It is not built on the win-win principle, but on the approaches based on the concepts of wining vs losing, strength vs weakness, and dominance vs subordination.

In the last few years, due to the latest political events, an aggressive rhetoric of power, and the deteriorating economic situation, the level of verbal and non-verbal aggression in the society has increased considerably. Calm, equal and positive conduct in a discussion and the use of honest argumentation are believed to be signs of weakness or femininity, which is essentially the same in Russia's dominant-gender discourse. In addition to the wide spread of Putin's personality cult, there is an overwhelming expansion of the general cult of a strong male personality. Machismo passes for charisma and leadership. The society does not condemn aggressive and disrespectful behavior of men towards others. However, women are not supposed to be aggressive, unless they are fighting for an idea approved by the authorities.

Dissidence is persecuted. The media and pro-governmental agents on social networks attack oppositional or critically-thinking people. It is not uncommon for people to 
lose their jobs for dissidence, and this happens not only at state enterprises, but also in private companies.

Constructivist and situationist approaches to ethics are not common in Russia. A popular view is "bad things are done by bad people with bad values". In the oppressive social context, the fundamental attribution error acquires an additional aspect: the conviction that bad things happen to bad people, and nothing bad can happen to the right people. Discussions of issues of discrimination, abuse, and violence are necessarily accompanied by victimblaming.

\section{How the distal context influences the Russian business ethics classroom}

The authoritarian style of state governance and business management, the cult of strong personality and power, respect for hierarchies, lack of political freedoms and the unfavorable economic situation, propagated by the ruling elite and based on the opposition to the West, the contradiction of the authentic values and values imposed on the society, lack of respect for the interests and problems of the individual on the state level and at the company level, machismo, gender stereotypes and growing misogyny, lack of the skill of conducting discussions on acute social issues - all these features of the distal context influence the Russian business ethics classroom in a specific way.

Dominant views, those that are considered right, are usually voiced very loudly, the marginalized ones are not given a voice. During discussions and while analyzing the reaction of the students to the concepts offered by the teacher, it is easy to see, which discourses are dominant, and which are marginal.

Another obstacle for maintaining an open and fruitful discussion in the classroom is the opinion that values and business are incompatible; this idea is very widely spread among experienced and employed students. Moreover, the common assumption is that business is fundamentally unethical and can not be cured. The conversation about values and ethics is perceived as ritual chatter that goes on in the media and in the speeches of the Russian authorities, but no one takes this chatter seriously. One of the students formulated this feeling very clearly: "At first, I felt like I was in a sect 'Be a good person' or 'Thirteenth commandment. Not included', later I realized that all these are real values". 
The political situation triggers self-censorship. The main social and political trends appear in the discussion: the supporters of the conservative point of view speak out loudly, while the rest keep silent. The critical debate on capitalism can be regarded as support of left political ideas that is inappropriate from the point of view of dominant political discourse.

In the Russian classroom, it is very difficult to discuss the issues of privilege and discrimination without those who are privileged being defensive or even aggressive, and those who are unprivileged keeping silence about their personal experience. In an environment, where both achievements and failures are associated with the people's personal features, sociological imagination, an understanding of how an individual's life experience is related to a broader social context is poorly developed (Mills, 1959).

Sharing personal stories or criticizing the status quo becomes unsafe. It seems that everyone understands that discrimination exists, but no one gives examples of their lives, which means that it exists somewhere out there, far away, and has nothing to do with Russian business and our lives, so it is not worth being discussed.

\section{The proximal context of the Russian classroom}

The framework and established practices of management education, student expectations, gender, age and status composition of a group of students, as well as the organization of classes (time and physical space) compose the proximal context of the Russian business ethics classroom.

Traditionally, both Soviet and post-Soviet Russian management education has paid more attention to the technical areas and skills, disregarding liberal arts. Consequently, programs have been overloaded with disciplines like applied mathematics, statistics, economics, and operations management (Mechitov \& Moskovich, 2004). In modern Russia, the idea that management education should be "practical" is still widespread, meaning that such education should provide a set of tested useful tools, practices and skills, with which a manager will manage resources (human, financial and others), avoid threats from the external environment and use opportunities, moving on the way to success and prosperity. In business discourse, due to the dominance of utilitarian view, people often regard themselves and other people as means of achieving success. Expensive education is considered an investment. No time for philosophy, let's get down to practice. The role of a teacher in this paradigm is narrowed to giving proven tools - well, now also taking 
into account ethical limitations. As a result of this approach to education, students form a very narrow perception of the tools; they cannot regard the entire system critically (Habermas, 1970), but see their task only in "fitting in" the existing structure, following the set of rules and successfully applying the tools they were told about.

How loudly these views will be voiced in the classroom depends on the gender, age, and status of people in the student group. I teach business ethics to MBA and bachelors of management, adults aged from 23 to 40, who already have another degree in technology, medicine, social sciences or the humanities. Most of the students have managerial experience. Those who consider themselves more entitled (based on their gender, age or working experience) can have an overwhelming influence on the whole group. They make attempts, often quite successfuly, to set the direction of the discussion, to determine what is permissible and what is not, what is considered correct from their point of view, how "in fact," everything happens in business, what is a "useful practice", and what is "just theories", how seriously this subject should be treated, how much expertise the teacher has, and whether or not the classes are worth attending. They have informal authority in the group and establish the rules and frameworks, often very oppressive ones. They grab the teacher's attention and create obstacles for free expression of other students' thoughts.

The urge for "efficiency" makes educational institutions save space and time in all possible ways: to make a course as short as possible, to bring in as many students as possible. It influences the learning space dramatically: less interactive activity, a lecture followed by a discussion instead of role-playing, discussion of the case in the "group-teacher" dialogue instead of student cooperation in small groups.

This is the way the distal and proximal contexts constraint the learning space of the Russian business ethics classroom, making it more formal, hierarchical, structured, censoring, taking the tremendous energy from students and a teacher, but less spontaneous, free or creative.

\section{Redesigning learning space to decrease the influence of the context}

As noted above, a learning space that promotes flexible framing should be created in order to encourage the development of moral imagination and reduce the level of ethical blindness. This means creating and fostering a climate of tolerance and pluralism in 
class, instead of fundamentalism and dogmatism suggested by the social environment (Palazzo, Krings, \& Hoffrage, 2013). In order to achieve this, a teacher needs to weaken the influence of distal and proximal context factors.

Speaking of proximal context, it is evident that not everything is within the teacher's control, but weakening the influence of group thinking, power dynamics, and time pressure is an achievable goal. One way to accomplish this is organizing out-of-class activities in the form of individual writing assignments. Written assignments and essays are not new teaching techniques, but in some cases they may acquire a new meaning and that is exactly what happens in the environment that is unfavorable for discussing critical issues.

Usually, written assignments are used to improve analytical and creative thinking and create self-awareness. Writing is a learning process: it is a way of exploring, formulating and rethinking one's understanding of the world. In the oppressive context, it becomes a tool for exploring one's personal experience and applying critical thinking to the dominant discourses safely, without resisting group pressure or fearing the classmates' negative opinion. One of the female students wrote the following:

I would really want to say, like my classmates did, that I am strong and independent, and men around me treat me as equal, that they do not objectify me, do not violate my rights, and the world is beautiful.

She realizes that her true opinion differed from the reality, but when facing the need to speak out in class, she would feel the need to go along the lines of the traditional wide-spread discourse.

Redesigning learning space in the suggested way allows the teacher to overcome time pressure and to pay equal attention to every student by means of carrying on a written dialogue with everyone. However, we do not only gain more time. Another important component of teaching ethics in management education is the relationship between students and the teacher. This relationship is an example, a training ground, which should demonstrate to the students the possibility and the advantages of interactions based on equality, tolerance and mutual understanding. It is extremely important because the social context offers the opposite - interaction based on authoritarianism and rigid hierarchy. 
Interestingly, some of the students in my class even formalized their essay in the form of a letter to me. Evidently, this type of task creates a space of freedom, where people express themselves explicitly. Here is a quote from the essay of a male student:

I apologize for the provocative arguments voiced by me and my classmates. I can not logically explain our behavior, but I'll try. You said that not everyone has the opportunity to achieve everything. I think that was the most embarrassing result of my young age. I perceived your words as "a voice from the past", which was saying, "You can not do anything, you are not given the chances, you are the son of a carpenter and a nurse!" And at that moment I wanted to violently oppose everything you said... Now I realize that it was silly of me...

It seems that the distal context is beyond the teacher's control. But aims of management education go far beyond helping students to become more effective pegs in the social or corporate machinery. One of the vital aims is helping the students to become critical thinkers and moral practitioners (Cunliffe, 2004). Reflexivity is an important source of ethics (Jørgensen \& Fatien Diochon, 2018), since it develops moral imagination and the ability to see all aspects of the problem. Indirectly, well-developed skills of critical reflexivity can weaken sich factors of distal context as a cult of strong personality and power, respect for hierarchies, an authoritarian style of management, lack of respect for the interests of an individual, lack of debating skills, the contradiction between the authentic values of the Russian society and the values imposed on by the ruling elite, misogyny, machismo, and gender stereotypes. The development of critical reflexivity itself is not the focus of this paper, therefore it will be discussed here to the extent necessary for the purpose of this paper.

The concept of reflexive practitioner and reflexivity has been debated in management and organizational study for some time (Calas \& Smircich, 1999; Chia, 1996; Hardy \& Clegg, 1997; Cunliffe, 2004; Jørgensen \& Fatien Diochon, 2018). Cunliffe by linking the idea on reflexive practitioner with the constructionist perception of reality, introduces the concept of critically reflexive practice that

offers a way of surfacing these pressures by encouraging us to examine the assumptions that decisions are justified solely on the basis of efficiency and profit, that there is one rational way of managing, that maintaining current managerial practice is paramount and that as professionals we know what is best for others. In examining these assumptions, we can uncover their limitations and possibilities, 
become less prone to becoming complacent or ritualistic in our thoughts and actions, and develop a greater awareness of different perspectives and possibilities and of the need to transform old ways of theorizing and managing. (Cunliffe, 2004)

Critical reflexivity is directed to organizational practice, politics, and social structures (Jørgensen \& Fatien Diochon, 2018).

The learning space, which unfolds under the influence of the authoritarian and oppressive distal and proximal contexts, limits possibilities for developing critical reflexivity. In an oppressive context, critical thinking is not directed against the context itself.

A constrained learning space can be redesigned by intensification of critical reflexivity in form of out-of-class activity. Individual writing assignments can be used to transfer part of the reflexive work to a safer environment.

There are two written assignments I usually give. The first one is an exercise "A Tale of Two Stories" from Giving Voice to Values (GVV) curriculum (www.GivingVoiceToValues. org). Rather than being focused on ethical analysis, this exercise focuses on ethical implementation and asks the questions: "What if I were going to act on my values? What would I say and do? How could I be most effective?" Students are invited to recall a situation in their work experience, when their values conflicted with what they were expected to do in a particular, non-trivial management decision, and they spoke up and acted to resolve the conflict and another case, in which they did not.

The second assignment is a reflexive essay, in which they write about what they got from the course, what affected them the most, how it is related to their work, what has changed in their understanding of things, and where does this lead them, what it has motivated them to think about.

The training tasks of writing exercises were different from the usual objectives pursued by such courses (development of critical thinking, research skills, reasoning, coherent position statement, etc.). The written tasks in our research were aimed at encouraging the development of critical reflexivity on complicated ethical issues. Therefore, the usual forms of evaluation and teacher's feedback could not work here. The discussion of the complicated subject matter called for another kind of feedback, something more personal and less evaluative. 
Since formal evaluation cannot be avoided, the formal aspects of work were assessed on the one-to-ten scale: comprehension and substantiveness. But there was no chance for the students to show poor performance: if the works were below the expected level, the authors were asked to rewrite them. A technique from narrative therapy was used to provide purposeful substantial feedback.

Cultural anthropologist Myerhoff says: "Unless we exist in the eyes of others, we may come to doubt even our own existence. Being is a social and psychological construct; it is something that is made, not given" (Myerhoff, 2007). The creators of narrative therapy, White and Epston used her ideas to develop the "outsider witness practice" (Walter \& Fox, 2012). The feedback of a witness is personal, not interpretive or evaluative, not hierarchical or authoritarian. This practice provides the opportunity to transform a formal, dry, hierarchical and authoritarian evaluation procedure into a prosocial and relational one, based on equality, freedom of expression and creativity. I used the spirit and general outline of this approach described by Walter and Fox (2012).

The witness' response to students' assignments consists of four parts: 1 ) identifying the expression, 2) identifying the image, 3) identifying resonance, 4) identifying transport. The first part is a must, in the other three the teacher can be creative.

Identifying the expression. A teacher (a witness) writes out some actual words or phrases used by a student that especially stood out of student's narrative and attracted the attention of a teacher, caught her eyes. I have chosen something that evoked a positive response, what I agreed with, what was based on shared values. Or something that positively characterized the narrator. This approach can ensure that a teacher stays connected to what a student has written, rather than being connected to her own hypotheses or interpretations.

Identifying the image. If these expressions evoke a visual image, and the teacher shares this image with the student, it gives more credibility to the response. No need to edify and explain what exactly this image means. Visual images are very powerful and are remembered in different ways (Walter \& Fox, 2012).

Identifying the resonance. If a witness (a teacher) has been drawn to a particular expression, then there may be a resonance with events of her personal life. It is not necessary to share the extensive details, but outlining it will show that a response is based on 
the experience, and "not authoritative truths based on an abstract theory" (Walter \& Fox, 2012).

Identifying the transport. It is rarely mentioned that an educational process is a twoway process, and a teacher is affected too. What new ideas has student's expressions or the whole narrative bought up for the teacher that she might not have without reading this story or essay? In narrative therapy, the story's effect on a witness called a "transport". A witness has been moved in some way from where she was before reading a narrative to the new place of understanding (Walter \& Fox, 2012). It should not be a serious transformation, just a little one. The knowledge that their stories influence the lives of others increases a sense of students' agency and significance of their life in connection with others.

In order to have the best effect, narrative practitioners recommend avoiding in a witness response applause or pointing out of positives, giving opinions or advice, hypothesizing, positive reinforcement, imposing values, sharing the personal experience "how I solved it" and processing one's own issues (Walter \& Fox, 2012).

The task of such a response is showing the managers an alternative, non-authoritative, and non-evaluative way of giving feedback. Sometimes students mention it in their essays.

The table 1 summarizes the types of activities used as part of the redesigned learning space for teaching business ethics in Russia. The table includes the dimensions of proximal and distal contexts. It also demonstrates how suggested activities helped to address such contextual factors.

\section{Table 1}

Types of learning activities and the way they affect various contextual factors

\begin{tabular}{lll}
\hline Type of learning activities & \multicolumn{1}{c}{ Aims } & \multicolumn{1}{c}{ Context factors overcome by the activity } \\
\hline & $\begin{array}{l}\text { Paying equal attention to every } \\
\text { student. }\end{array}$ & Proximal: \\
& Neutralizing situational and & - group thinking; \\
proximal context factors. & - time pressure; \\
& Promoting critical reflexivity. & - power dynamics; \\
Out-of- class activity & Providing an example of a non- & - contradiction between true and imposed values; \\
& hierarchial interaction. & - lack of public discussion skills; \\
& & - authoritarian management style; \\
& & - cult of strong personality and power; \\
& - respect for hierarchies.
\end{tabular}




\begin{tabular}{|c|c|c|}
\hline Type of learning activities & Aims & Context factors overcome by the activity \\
\hline Writing assignments & $\begin{array}{l}\text { Paying equal attention to every } \\
\text { student. } \\
\text { Neutralizing situational and } \\
\text { proximal context factors. } \\
\text { Promoting critical reflexivity. } \\
\text { Providing an example of non- } \\
\text { hierarchial interaction. }\end{array}$ & $\begin{array}{l}\text { Proximal: } \\
\text { - group thinking; } \\
\text { - time pressure; } \\
\text { - power dynamics; } \\
\text { Distal: } \\
\text { - contradiction between true and imposed values; } \\
\text { - lack of public discussion skills; } \\
\text { - authoritarian management style; } \\
\text { - cult of strong personality and power; } \\
\text { - lack of respect for individuals' interests; } \\
\text { - respect for hierarchies; } \\
\text { - gender stereotypes; } \\
\text { - misogony; } \\
\text { - machismo. }\end{array}$ \\
\hline Reflexive essay & $\begin{array}{l}\text { Paying equal attention to every } \\
\text { student. } \\
\text { Neutralizing situational and } \\
\text { proximal context factors. } \\
\text { Promoting critical reflexivity. } \\
\text { Providing an example of non- } \\
\text { hierarchial interaction. }\end{array}$ & $\begin{array}{l}\text { Proximal: } \\
\text { - group thinking; } \\
\text { - time pressure; } \\
\text { - power dynamics; } \\
\text { Distal: } \\
\text { - contradiction between true and imposed values; } \\
\text { - lack of public discussion skills; } \\
\text { - authoritarian management style; } \\
\text { - cult of strong personality and power; } \\
\text { - lack of respect for individuals' interests; } \\
\text { - respect for hierarchies; } \\
\text { - gender stereotypes; } \\
\text { - misogony; } \\
\text { - machismo. }\end{array}$ \\
\hline $\begin{array}{l}\text { Storytelling and } \\
\text { reflexive exercises }\end{array}$ & $\begin{array}{l}\text { Paying equal attention to every } \\
\text { student. } \\
\text { Neutralizing situational and } \\
\text { proximal context factors. } \\
\text { Promoting critical reflexivity. } \\
\text { Providing an example of non- } \\
\text { hierarchial interaction. }\end{array}$ & $\begin{array}{l}\text { Proximal: } \\
\text { - group thinking; } \\
\text { - time pressure; } \\
\text { - power dynamics; } \\
\text { Distal: } \\
\text { - contradiction between true and imposed values; } \\
\text { - lack of public discussion skills; } \\
\text { - authoritarian management style; } \\
\text { - cult of strong personality and power; } \\
\text { - lack of respect for individuals' interests; } \\
\text { - respect for hierarchies; } \\
\text { - gender stereotypes; } \\
\text { - misogony; } \\
\text { - machismo. }\end{array}$ \\
\hline
\end{tabular}




\begin{tabular}{|c|c|c|}
\hline Type of learning activities & Aims & Context factors overcome by the activity \\
\hline $\begin{array}{l}\text { "Outsider witness" } \\
\text { feedback }\end{array}$ & $\begin{array}{l}\text { Paying equal attention to every } \\
\text { student. } \\
\text { Neutralizing situational and } \\
\text { proximal context factors. } \\
\text { Promoting critical reflexivity. } \\
\text { Providing an example of non- } \\
\text { hierarchial interaction. } \\
\text { Demonstrating an non- } \\
\text { authoritative, non-evaluative, } \\
\text { and prosocial way of giving } \\
\text { feedback. }\end{array}$ & $\begin{array}{l}\text { Proximal: } \\
\text { - group thinking; } \\
\text { - time pressure; } \\
\text { - power dynamics; } \\
\text { Distal: } \\
\text { - contradiction between true and imposed values; } \\
\text { - lack of public discussion skills; } \\
\text { - authoritarian management style; } \\
\text { - cult of strong personality and power; } \\
\text { - lack of respect for individuals' interests; } \\
\text { - respect for hierarchies; } \\
\text { - gender stereotypes; } \\
\text { - misogony; } \\
\text { - machismo. }\end{array}$ \\
\hline
\end{tabular}

Source: Own elaboration.

As a whole, this approach provides great support in liberation from the oppressive context and conducting friendly and productive learning space for intensification of critical reflexivity development. However, implementation was challenging. The problem was that many students were not ready for reflexive analysis. Storytelling was a simple task, but there was a lack of reflexive analysis practice. All this just confirms that the authoritarian environment, in which students are studying and working, does not contribute to the development of reflexivity, so the direction of development was chosen correctly. However, the use of the approach required considerable time and intellectual efforts, on both the teacher's and the students' part, because with some students several iterations were necessary, such as rewriting or answering clarifying questions.

\section{Conclusion}

Oppressive social context constraints learning space in a business ethics classroom, reinforcing the dominant culture, promoting rigid cognitive framing, and making obstacles for the development of critical reflexivity. Typical of an authoritarian culture, power relations turn traditional educational methods like in-class group activities into transmitters of the dominant discourses and create obstacles to a meaningful discussion on ethical issues.

While distal contextual factors are beyond the teacher's control, the learning space can be redesigned in order to weaken the influence of the proximal context in the form of group and time pressure and to create a safer, more trustful environment. This goal can be achieved by intensifying critical reflexivity in the form of individual writing assign- 
ments, and with the support of special kind of teacher's feedback aimed to demonstrate to the students an alternative, non-authoritarian, mutually respectful and non-evaluative way to discuss ethical issues.

The classes that I taught and then analyzed in connection with the present research provided elaborate proof of the fact that people do not always articulate in public their real thoughts and opinions; also, silence does not mean consent. For many students, "fitting in" with the rest of the group turned out more valuable than expressing their own opinion on the subject raised by the teacher. Part of the reason that should be taken into consideration by a teacher is that any interactions during their course are limited to several dozen academic hours, while the classmates would be around each other for several more years, so the pressure of conformity is higher than the desire to speak out.

I have collected a solid number of students' reflexive essays and exercises, which require further study. There can be several research areas, from identifying the dominant and marginalized ethical narratives of Russian management students to analyzing the ways Russian employees defend their values at their workplace. The latter can become part of a comparative study, which would involve other working and social contexts -more or less oppressive- within the framework of the Giving Voice to Values programme.

I can suggest several ways of improving the above-mentioned teaching practices. One of such ways could be adding additional questions in the essay, aimed at developing the students' reflexivity about the influence of proximal and distal contexts on the process of making ethical decisions in their workplace. The main goal is to transform this issue from a theoretical concept into an integral part of the students' personal experience.

\section{References}

Adizes, I. (2013). Managerial Problems of Russia. Downloaded on 24 May, 2018, from http:// www.ichakadizes.com/managerial-problems-of-russia/.

Arendt, H. (1963). Eichman in Jerusalem: A report on the banality of evil. New York: The Vinking Press.

Becker, U., \& Vasileva, A. (2016). Russia's political economy re-conceptualized: A changing hybrid of liberalism, statism, and patrimonialism. Journal of Eurasian Studies, 8, 83-96.

Berger, P., \& Luckmann, T. (1966). The social construction of reality. New York: Anchor Books.

Brookfield, S. (2005). The power of critical theory for adult learning and teaching. Maidenhead: Open University Press. 
Calas, M., \& Smircich, L. (1999). Past postmodernism? Reflections and tentative directions. Academy of Management Review, 24(4), 649-671.

Chia, R. (1996). The problem of reflexivity in organizational research: Towards a postmodern science of organization. Organization, 3(1), 31-59.

Credit Suisse Research Institute. Global Wealth Report 2017. Downloaded on 24 May 2018 https:// www.credit-suisse.com/corporate/en/research/research-institute/global-wealthreport.html

Cunliffe A. (2004). On becoming a critically reflexive practitioner. Journal of Management Education, 28(4).

Freedom House. Freedom in the World 2018, Russia. https://freedomhouse.org/report/freedomworld/2018/russia.

Gioia, D. (1992). Pinto fires and personal ethics: A script analysis of missed opportunities. Journal of Business Ethics, 11, 379-389.

Giving Voice to Values Curriculum https://www.darden.virginia.edu/ibis/initiatives/givingvoice-to-values/

Golovin, N., \& Sibirev, V. (2016). The Possibility of Cultural Recession in Russia since 2010: Reflections on Values Research. Journal of Sociology and Social Anthropology, XIX(3), 86.

Habermas J. (1970). Technology and science as "ideology". In J. Shapiro (ed.), Toward a Rational Society: Student protest, science, and politics. Boston: Beacon Press.

Hardy, C., \& Clegg, S. (1997). Relativity without relativism: Reflexivity in post-paradigm organization studies. British Journal of Management, 8(Special Issue), S5-S17. https:// www.opendemocracy.net/od-russia/ilya-matveev/russia-inc

Jørgensen, K., \& Fatien Diochon, P. (2018). Creative coaching in the organizational space of appearance. Paper presented at the LAEMOS Conference, Buenos Aires, 22-24 March.

Levada Center (2018). Enemies of Russia. https://www.levada.ru/2018/01/10/vragi-rossii/.

Levada-Center research commissioned by Sberbank (2013). Consumer behavior through the lenses of trust and responsibility. Downloaded on 24 May 2018 http://gtmarket.ru/ files/news/5390/Consumer_Behavior_Trust_and_Responsibility_of_Russian_Society_ February_2013.pdf

Louis, D., \& Fatien Diochon P. (2018). The coaching space: A production of power relationships in organizational settings. Organization, 25(6), 710-731.

Marcuse, H. (1991). One-dimensional man: studies in the ideology of advanced industrial society, $2^{\text {nd }}$ ed., Boston: Beacon Press.

Matveev, I. (2016). Russia, Inc. Downloaded on 20 May 2018 from https://www.opendemocracy. net/od-russia/ilya-matveev/russia-inc.

Mechitov, A., \& Moskovich, H. (2004). Specifics and Dynamics of Russian Business Education, https://www.westga.edu/ bquest/2004/russia.htm. 
Memorial, the Human Rights Center (2017). Violence and Lawlessness Against Citizens ans Justice. https://memohrc.org/ru/news/nasilie-i-bezzakonie-protiv-grazhdan-i-prava.

Mills, C. (1959). The Sociological Imagination. New York: Oxford University Press.

Myerhoff, B. (2007). Stories as equipment for living. Michigan: University of Michigan Press.

Palazzo, Krings, \& Hoffrage (2013). Ethical Blindness. Journal of Business Ethics, February.

Paneyakh, E. (2016). Pardon impossible to execute: The values and actions of Russians. Downloaded on 18 May 2018 from https://theoryandpractice.ru/videos/1006-ella-paneyakh-kaznitnelzya-pomilovat-tsennosti-i-postupki-rossiyan.

Paul, C., \& Matthews, M. (2016). The Russian "Firehose of Falsehood" Propaganda Model. Why It Might Work and Options to Counter It. https://www.rand.org/pubs/perspectives/ PE198.html.

Schulmann, E. (2014). The realm of Political Imitation. https://www.vedomosti.ru/opinion/ articles/2014/08/15/carstvo-imitacii.

Shoukry, H. (2016). Coaching for Emancipation: A framework for coaching in oppressive environments. International Journal of Evidence Based Coaching and Mentoring, 14(2).

Transparency International's Corruption Perceptions Index 2017. Downloaded on 10 May 2018 https://www.transparency.org/country/RUS.

Ukraine Crisis Media Center (2018). Image of Europe on Russian TV. http://ucmc.org.ua/wpcontent/uploads/2018/02/Image-of-Europe-on-Russian-TV-long.pdf.

Walter, S., \& Fox, H. (2012). Narrative therapy and outsider witness practice: Teachers as a community of acknowledgment. Educational \& Child Psychology, 29(2).

Young, I. M. (2000). Five Faces of Oppression. In Adams, M., et al. (eds.), Readings for diversity and social justice (pp. 35-49). New York: Routledge.

Yushina, V. (2014). A comparative analysis of American and Russian styles of leadership on the ground of behavioral and situational theories. Downloaded on 24 May 2018 from http:// ekonomika.snauka.ru/2014/02/3837.

Licencia Creative Commons CC BY 4.0 
